\title{
Decreased Expression and Uncoupling of Endothelial Nitric Oxide Synthase in the Cerebral Cortex of Rats with Thioacetamide-Induced Acute Liver Failure
}

\author{
Krzysztof Milewski (D, Anna Maria Czarnecka (D), Jan Albrecht (D) and Magdalena Zielińska *(D) \\ Department of Neurotoxicology, Mossakowski Medical Research Institute, Polish Academy of Sciences, \\ 5 Pawińskiego Str, 02-106 Warsaw, Poland; kmilewski@imdik.pan.pl (K.M.); aczarnecka@imdik.pan.pl (A.M.C.); \\ jalbrecht@imdik.pan.pl (J.A.) \\ * Correspondence: mzielinska@imdik.pan.pl; Tel.: +48-22-6086470
}

check for

updates

Citation: Milewski, K.; Czarnecka,

A.M.; Albrecht, J.; Zielińska, M.

Decreased Expression and

Uncoupling of Endothelial Nitric

Oxide Synthase in the Cerebral Cortex

of Rats with Thioacetamide-Induced

Acute Liver Failure. Int. J. Mol. Sci.

2021, 22, 6662. https://doi.org/

$10.3390 /$ ijms 22136662

Academic Editor: G. Jean Harry

Received: 28 May 2021

Accepted: 18 June 2021

Published: 22 June 2021

Publisher's Note: MDPI stays neutra with regard to jurisdictional claims in published maps and institutional affiliations.

Copyright: (C) 2021 by the authors Licensee MDPI, Basel, Switzerland. This article is an open access article distributed under the terms and conditions of the Creative Commons Attribution (CC BY) license (https:/ creativecommons.org/licenses/by/ $4.0 /)$

Abstract: Acute liver failure (ALF) is associated with deregulated nitric oxide (NO) signaling in the brain, which is one of the key molecular abnormalities leading to the neuropsychiatric disorder called hepatic encephalopathy (HE). This study focuses on the effect of ALF on the relatively unexplored endothelial NOS isoform (eNOS). The cerebral prefrontal cortices of rats with thioacetamide (TAA)induced ALF showed decreased eNOS expression, which resulted in an overall reduction of NOS activity. ALF also decreased the content of the NOS cofactor, tetrahydro-L-biopterin (BH4), and evoked eNOS uncoupling (reduction of the eNOS dimer/monomer ratio). The addition of the NO precursor L-arginine in the absence of $\mathrm{BH} 4$ potentiated ROS accumulation, whereas nonspecific NOS inhibitor L-NAME or EDTA attenuated ROS increase. The ALF-induced decrease of eNOS content and its uncoupling concurred with, and was likely causally related to, both increased brain content of reactive oxidative species (ROS) and decreased cerebral cortical blood flow (CBF) in the same model.

Keywords: acute liver failure; nitric oxide synthase uncoupling; cerebral blood flow; tetrahydrobiopterin

\section{Introduction}

Hepatic encephalopathy (HE) is a neuropsychiatric disorder associated with acute (ALF) or chronic liver failure. Brain edema and impaired cerebral blood flow (CBF) are the two major manifestations of HE [1-3]. These two interrelated impairments are associated with the induction of oxidative and nitrosative stress (ONS) triggered by different stimuli. The excessive formation of reactive oxygen species (ROS) in HE-affected brain has a variety of consequences for the genome and proteome, as documented by in vitro and in vivo studies [4,5]. While N-methyl-D-aspartate (NMDA) receptor-mediated accumulation of intracellular calcium and neuroinflammation clearly appear to induce ONS in HE [5-7], ROS generation is also associated with the excessive production of superoxide anion $\left(\mathrm{O}_{2}{ }^{-}\right)$, resulting from the p47phox subunit of the NADPH oxidase enzyme, as shown in cultured rat astrocytes and cortical mouse brain slices [8]. Beside the activation of oxidizing enzymes that directly produce oxygen radicals, oxidative stress also leads to the generation of nitric oxide (NO) by nitric oxide synthases (NOSs) [9]. However, being the source of reactive nitrogen species (RNS), NOS isozymes, if uncoupled, generate $\mathrm{O}_{2}{ }^{-}$, and therefore, will support direct oxidation [10]. The contribution of NOS isoforms to ALF-induced alterations in brain metabolism is still not entirely clear. Present knowledge of the responses of the endothelial isoform of NOS, eNOS, which is a key player in the regulation of CBF [11], lags behind that of the other isoforms. NO production altered by eNOS is expected to modulate the magnitude of ONS in the whole brain and, specifically, brain vasculature homeostasis. In theory, alterations in eNOS activity in ALF-affected brain may be linked to either reduced eNOS protein content and/or to the "uncoupling" of the enzyme by adverse 
regulation of well-defined "redox switches" in the eNOS enzyme or up-/down-stream signaling molecules [12]. Previously, eNOS uncoupling and subsequent oxidative stress were recorded in a cirrhotic liver, and were associated with a decreased level of the eNOS cofactor, tetrahydro-L-biopterin (BH4) [13]. Additionally, BH4 supplementation improved the endothelial dysfunction of cirrhotic liver [14,15]. It therefore appeared to be worthwhile to analyze the eNOS status in ALF-affected brain. Additional questions addressed in this study are whether and to what degree ALF-induced changes affect NO production and CBF in the whole brain.

\section{Results}

\subsection{Rat Model of Acute Liver Failure}

TAA-induced ALF is a commonly used animal model of HE [16-19]. Twenty-four hours after the third injection of TAA (96th $\mathrm{h}$ of the experiment), the rats showed visible symptoms of ALF with HE: reduced motor function with stupor or precoma state, and decreased food intake, resulting in $15-20 \%$ body weight loss in comparison to control animals (Table 1 ). The mortality rate was $\sim 10 \%$, which, in the spectrum of different ALF rat models, is considered to be moderate [20,21]. Blood plasma biochemical tests revealed a significant increase of ammonia concentration and elevated levels of liver enzymes in TAA-treated rats (Table 1). Hematoxylin and eosin staining revealed decomposition of hepatic parenchyma in TAA-treated rats, with corresponding inflammatory infiltration and massive necrosis of hepatocytes (Figure 1).
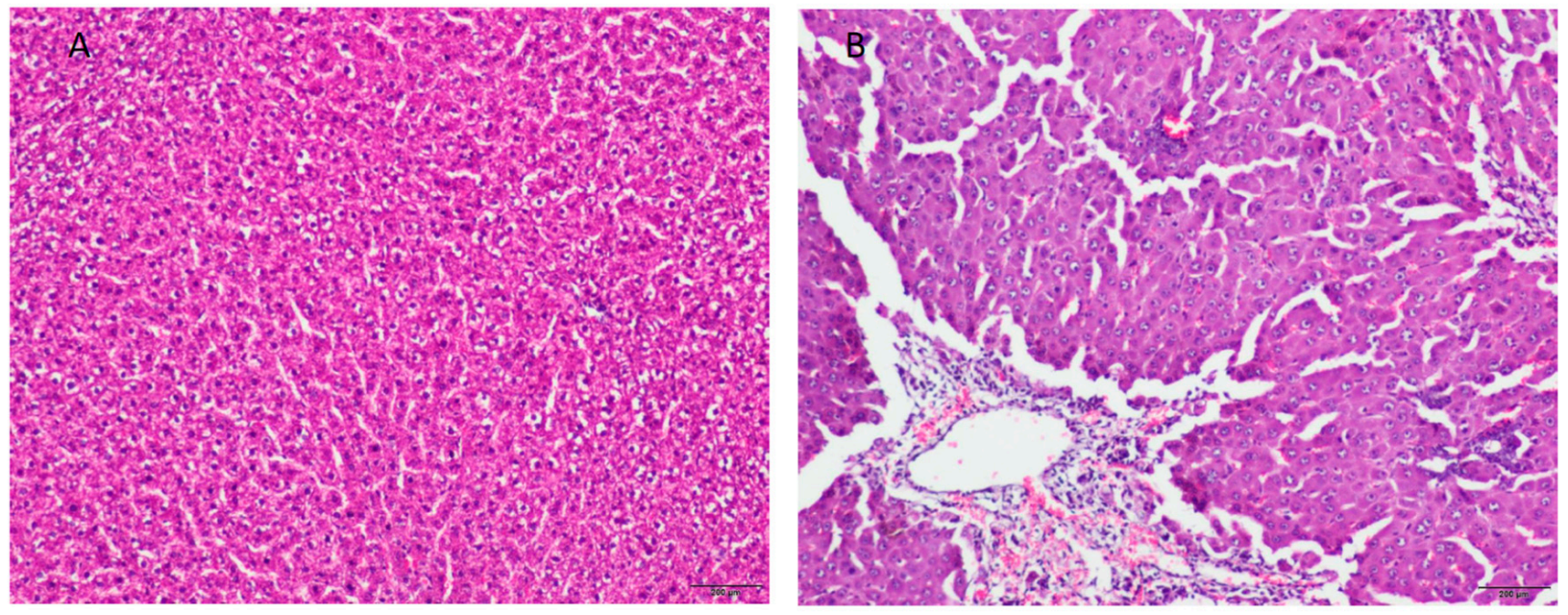

Figure 1. TAA-induced changes in hepatic histopathology. Micrographs of hematoxylin-eosin stained liver sections from control (A) and TAA-treated (B) rats. The histology studies of the control liver showed the normal histological appearance of liver tissue (A), whereas the TAA-treated liver section revealed widespread intracellular vacuolization, centrilobular bridging hepatocellular necrosis, and infiltration of inflammatory cells (B). Scale bars $=200 \mu \mathrm{m}$. Plasma level of ammonia $\left(\mathrm{NH}_{3}\right)$ and activities of control and TAA-treated rats. 
Table 1. Rat model characteristics. Plasma level of ammonia $\left(\mathrm{NH}_{3}\right)$ and activities of liver enzymes: aspartate aminotransferase (AST), alanine amino transferase (ALT), and gamma-glutamyl transpeptidase (GGTP). Initial, final rat body weights and rate of weight gain of control and TAA-treated rats $(\mathrm{n}=5)$.

\begin{tabular}{ccc}
\hline & Control & TAA \\
\hline AST $(\mathrm{GOT})(\mathrm{U} / \mathrm{L})$ & $142.3 \pm 11.7$ & $977.12 \pm 124.38^{* * *}$ \\
$\mathrm{ALT}(\mathrm{GPT})(\mathrm{U} / \mathrm{L})$ & $54.62 \pm 2.03$ & $325.41 \pm 43.84^{* * *}$ \\
$\mathrm{GGTP}(\mathrm{U} / \mathrm{L})$ & $2.65 \pm 0.13$ & $4.23 \pm 0.33^{* *}$ \\
$\mathrm{NH}_{3}(\mu \mathrm{mol} / \mathrm{L})$ & $64.54 \pm 5.29$ & $132.12 \pm 18.64^{* *}$ \\
Initial body weight $(\mathrm{g})$ & $208.5 \pm 7.23$ & $217.4 \pm 8.1$ \\
Final body weight $(\mathrm{g})$ & $224.8 \pm 9.47$ & $196.1 \pm 14.65$ \\
Body weight diff. $(\mathrm{g})$ & 16.3 & -21.3 \\
\hline
\end{tabular}

Abbreviation: AST, aspartate aminotransferase; ALT, alanine amino transferase; GGTP, gamma-glutamyl transpeptidase. Values are mean $\pm \mathrm{SD}$ obtained as described in Materials and methods. ${ }^{* * *} p<0.001{ }^{* *} p<0.01$ vs. control group, $\mathrm{n}=5$.

\subsection{The Expression of NOS Isoforms in the Liver and Prefrontal Cortex}

Increased expression of eNOS and iNOS was detected in the liver of TAA-treated rats (Figure 2); this result for eNOS was in line with an earlier observation made under an identical TAA treatment protocol [22]. By contrast, in the prefrontal cortex of TAA rats, a selective $\sim 60 \%$ decrease of eNOS protein was observed, whereas nNOS and iNOS protein levels remained unchanged (Figure 3).

(A)

(B)
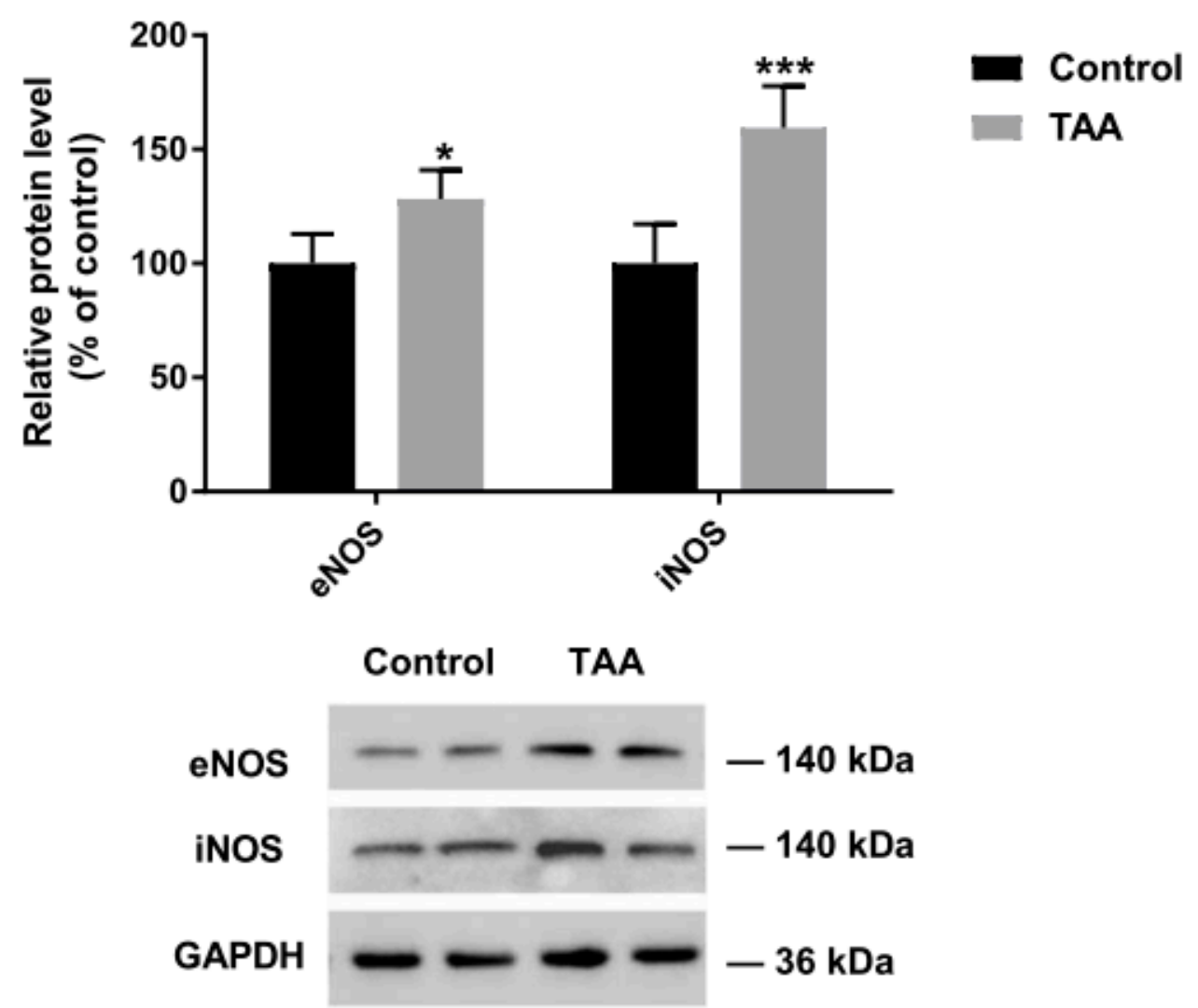

Figure 2. TAA treatment induces eNOS and iNOS protein level in liver. The relative protein level of control and TAA rats (A). Results are mean $\pm \mathrm{SD}(\mathrm{n}=5)$. Significant difference vs. control ${ }^{*} p<0.05 ;{ }^{* * *} p<0.001$. Immunostaining of eNOS and iNOS in the liver $(\mathbf{B})$. 
Strong immunofluorescence staining of eNOS was observed in control brain capillaries and microvessels (Figure 3), whereas lower immunostaining intensity was present in the vasculature isolated from TAA rat brain, where the enzyme was heterogeneously localized (Figure 3).

A

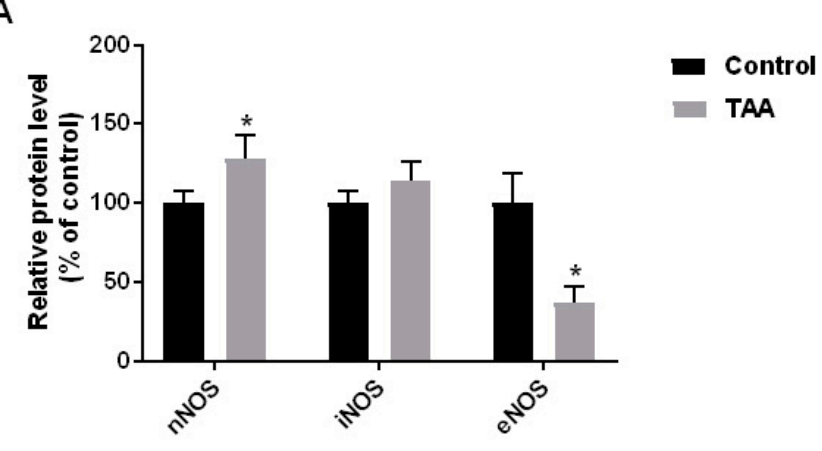

B

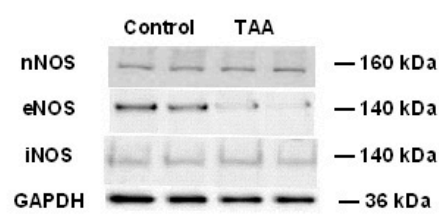

c

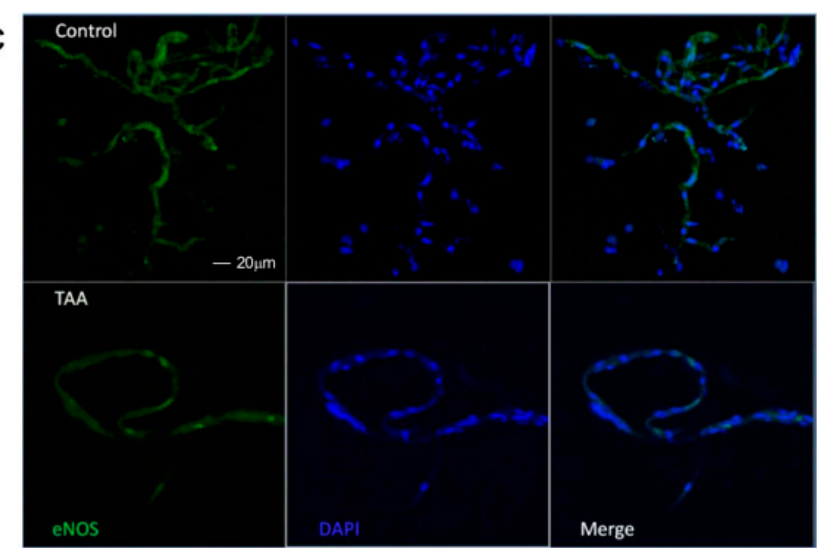

D

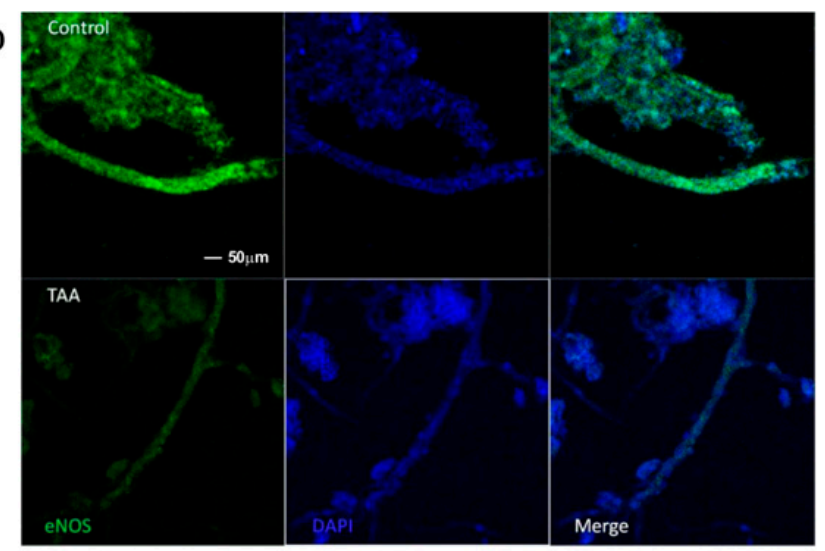

Figure 3. TAA induces eNOS depletion in rat brain cortex. Left panel $(\mathbf{A}, \mathbf{B})$ Western blot analysis of the relative protein level of $n N O S$, iNOS and eNOS in prefrontal cortex of control and TAA rats. Results are mean $\pm S D(n=5)$ Significant difference vs. control ${ }^{*} p<0.05$. Right panel (C,D) confocal microscopy images of isolated rat brain capillaries (C) and microvessels (D) of control and TAA rats. Immunofluorescence staining for eNOS. Nuclei were counterstained with DAPI (blue).

\subsection{NOx Measurement and Nitration of Plasma and Prefrontal Cortex Proteins in TAA Rats}

The NOx concentration was increased in plasma but not in the prefrontal cortex of TAA rats (Figure 4). In line with reports of increased NOS activity as a hallmark of acute liver damage [23], NOx level accompanies increased nitration of blood plasma proteins in TAA rats (Figure 4). This correlation is a well-established consequence of ONS induction and elevated NOS activity in organs of experimental animals and humans affected by different degenerative and/or inflammatory diseases [24-26], including human HE [27]. Accordingly, TAA treatment increased the total brain prefrontal cortical level of nitrated proteins (Figure 4). 

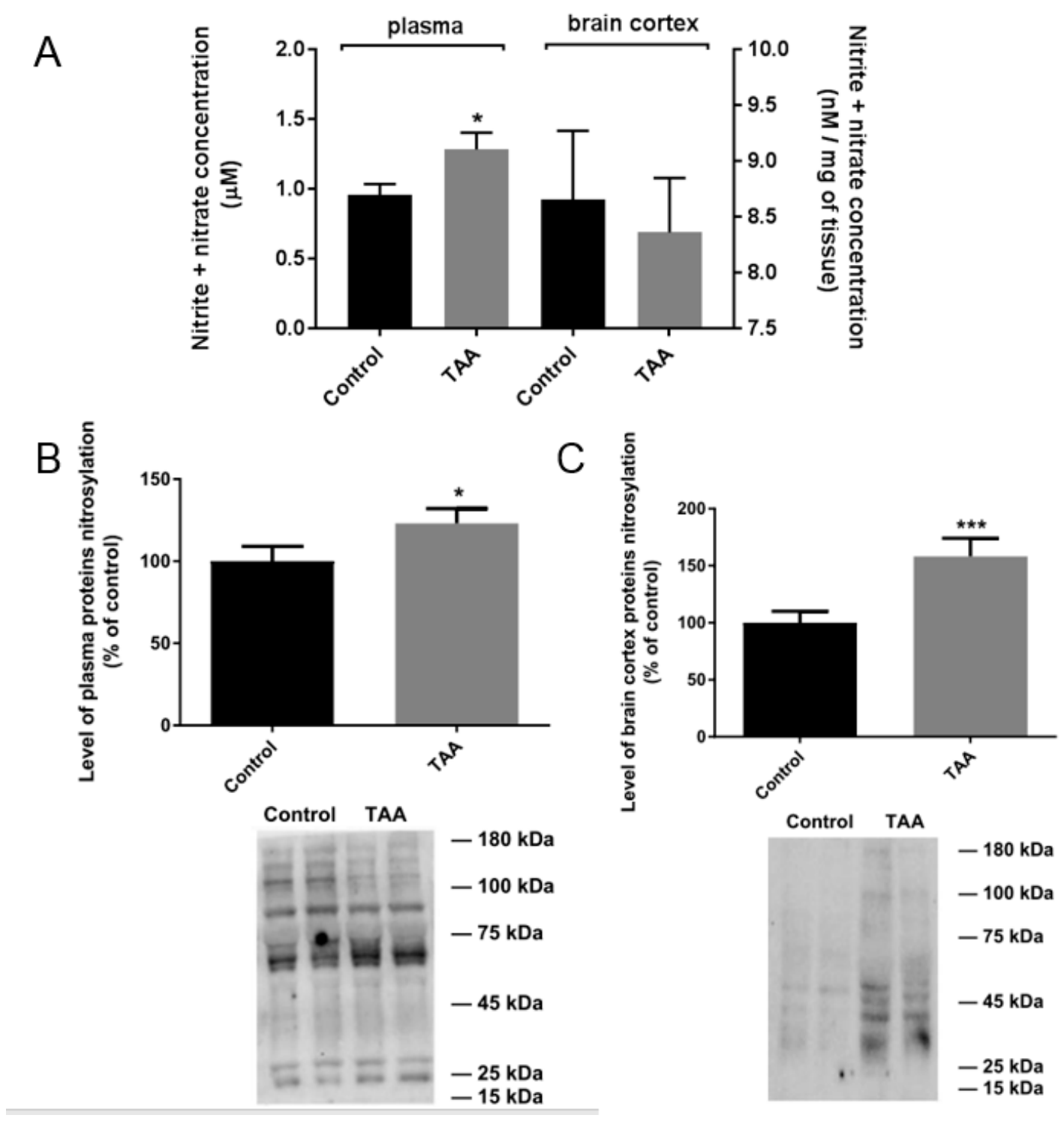

Figure 4. NOx (nitrite + nitrate) concentration in plasma and brain prefrontal cortex of control and TAA rats (A). Results are mean \pm SD ( $n=5)$ Significant difference vs. control * $p<0.05$. Western blot analysis of protein nitration in rat blood plasma (B) and prefrontal cortex $(C)$ of control and TAA rats. Results are mean \pm SD $(n=5)$. Significant difference vs. control ${ }^{*} p<0.05 ;{ }^{* * *} p<0.001$.

\section{4. eNOS Dimer/Monomer Ratio Status and BH4 Level in the Brain Prefrontal Cortex}

Both the total level of eNOS dimers and the eNOS dimer/monomer ratio were lowered in the prefrontal cortex of TAA-treated animals, suggesting that eNOS uncoupling, in addition to decreased eNOS protein, is another eNOS-related brain abnormality in ALF (Figure 5).

In TAA-treated rats, the level of NOS cofactor $\mathrm{BH} 4$ was not significantly affected in blood plasma, but was decreased by $\sim 60 \%$ in the prefrontal cortex (Figure 5). 
A

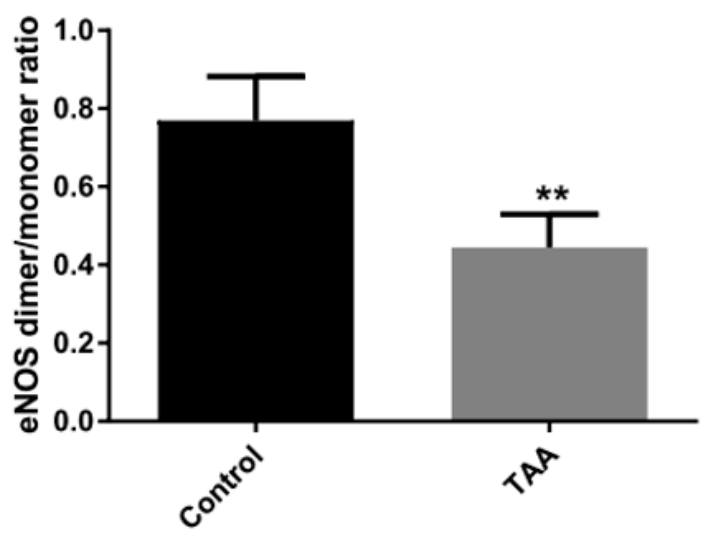

B

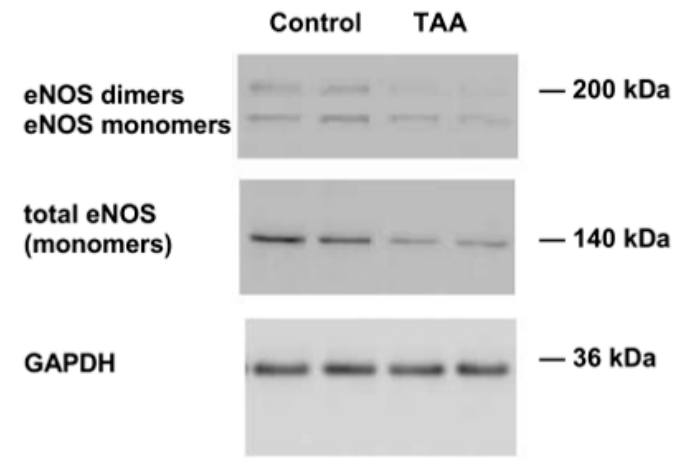

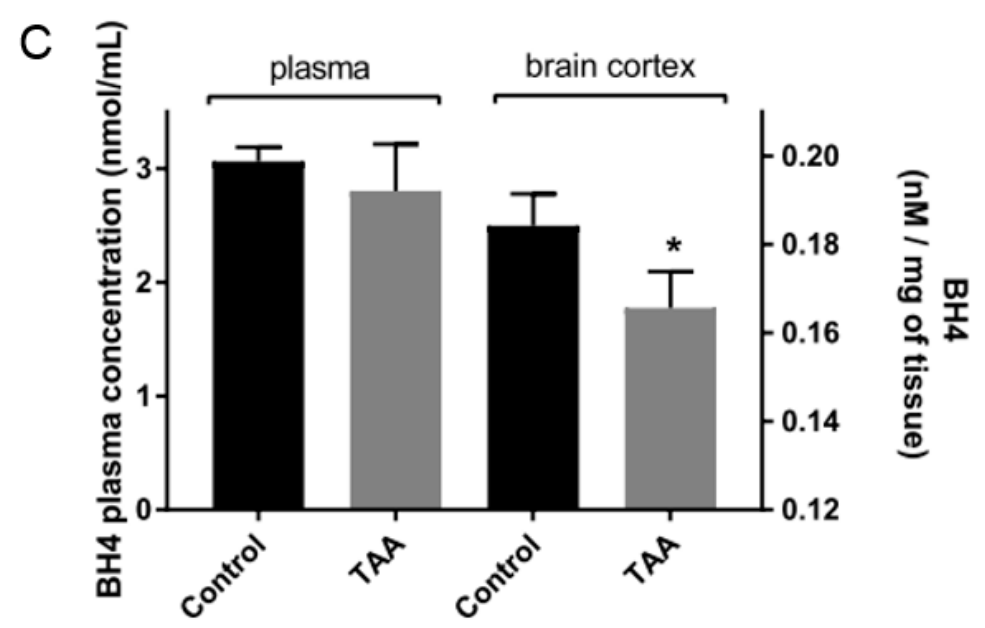

Figure 5. TAA impairments brain eNOS coupling. Western blot analysis of eNOS dimer/monomer ratio in rat prefrontal cortex of control and TAA rats $(\mathbf{A})$. Results are mean $\pm \mathrm{SD}(\mathrm{n}=5)$. Significant difference vs. control ${ }^{* *} p<0.01$. Immunostaining of eNOS dimmers and monomers $(\mathbf{B})$. Measurement of $\mathrm{BH} 4$ concentration in rat blood plasma and prefrontal cortex of control and TAA rats $(C)$. Results are mean \pm SD $(n=5)$ Significant difference vs. control * $p<0.05$.

\subsection{The Relative Contribution of NOS Isoforms to ROS Production in the Prefrontal Cortex}

The total ROS production was elevated by $\sim 20 \%$ in the prefrontal cortex of TAA rats (Figure 6). The addition of NOS substrate L-arginine significantly enhanced ROS production in both control and TAA rat brain homogenates, whereas nonspecific NOS inhibitor L-NAME or EDTA abolished ROS increase, underscoring the NOS-dependent nature of ROS generation. The addition of $\mathrm{BH} 4$, which is the main cofactor contributing to NOS coupling, significantly reduced ROS level in both control and TAA homogenate supplemented with L-arginine (Figure 6). 

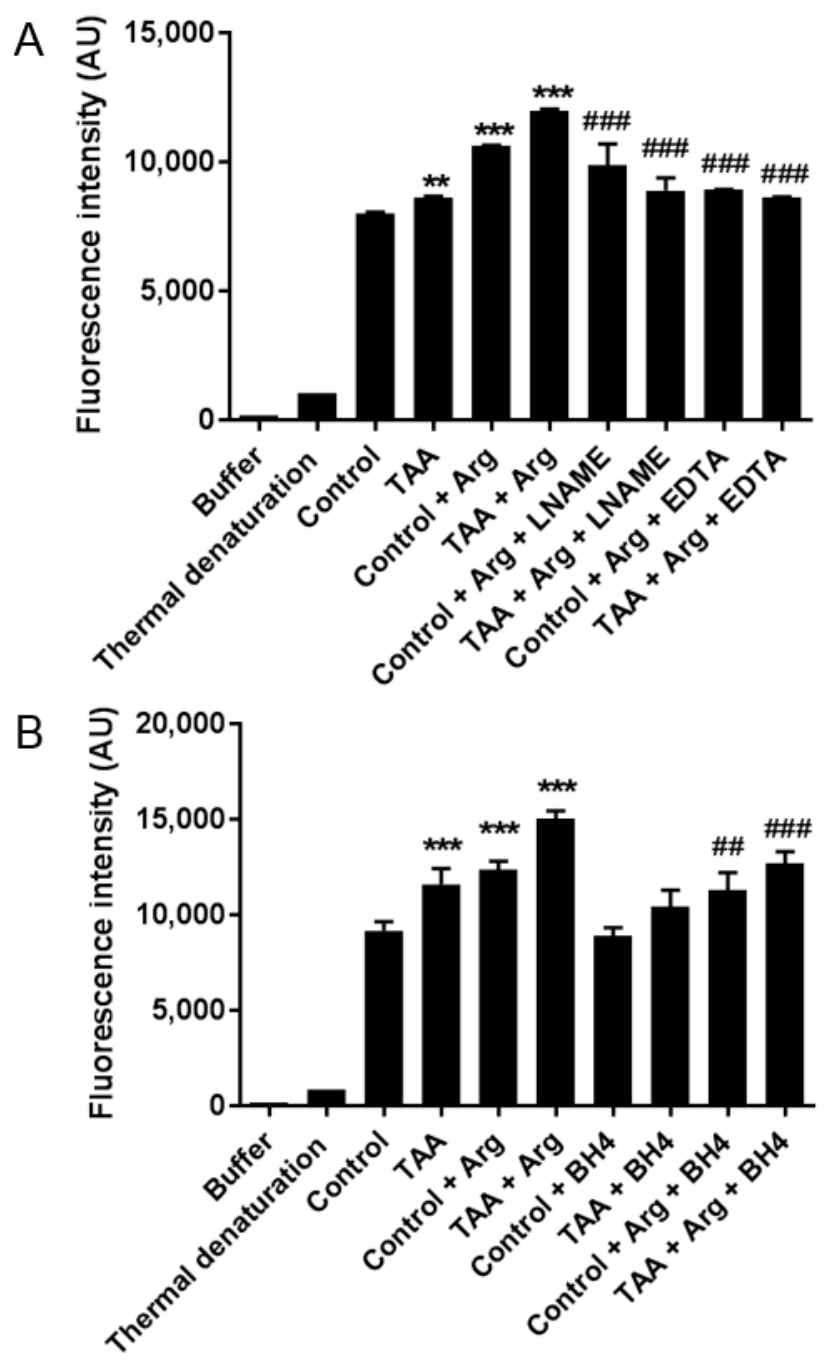

Figure 6. Uncoupled eNOS participates in TAA dependent enhancement of ROS production in the brain. Measurement of total ROS production in TAA rat brain cortex homogenate: effect of L-NAME and EDTA (A); effect of BH4 (B). Results are mean \pm SD $(n=5)$. Significant difference vs. control ** $p<0.01 ;{ }^{* * *} p<0.001 ; \#$; $p<0.01$; \#\#\# $p<0.001$ vs. corresponding (+Arg) group.

\subsection{Total NOS Activity}

Total NOS activity was significantly reduced in the prefrontal cortex of TAA rats (Figure 7). Calcium ion chelation reduced the enzyme activity of control samples by $\sim 70 \%$, while also abrogating the difference between the activity of NOS in the prefrontal cortex of control and TAA rats. These results imply that (i) the majority of enzyme activity in the brain homogenate is attributable to eNOS and/or nNOS (Figure 7), (ii) TAA treatment does not affect the fraction of NOS activity which is attributable to iNOS.

\subsection{CBF in the Prefrontal Cortex of TAA Rats}

Given the well documented role of eNOS as a key regulator of microvascular tone, it appeared to be worthwhile to examine the effect of TAA treatment in the present model on CBF in the brain prefrontal cortex. MRI analysis revealed that TAA treatment reduced CBF by $40 \%$ (Figure 8 ), which can likely be reconciled with a decrease of eNOS expression (Figure 3) and its uncoupling (Figure 6). 


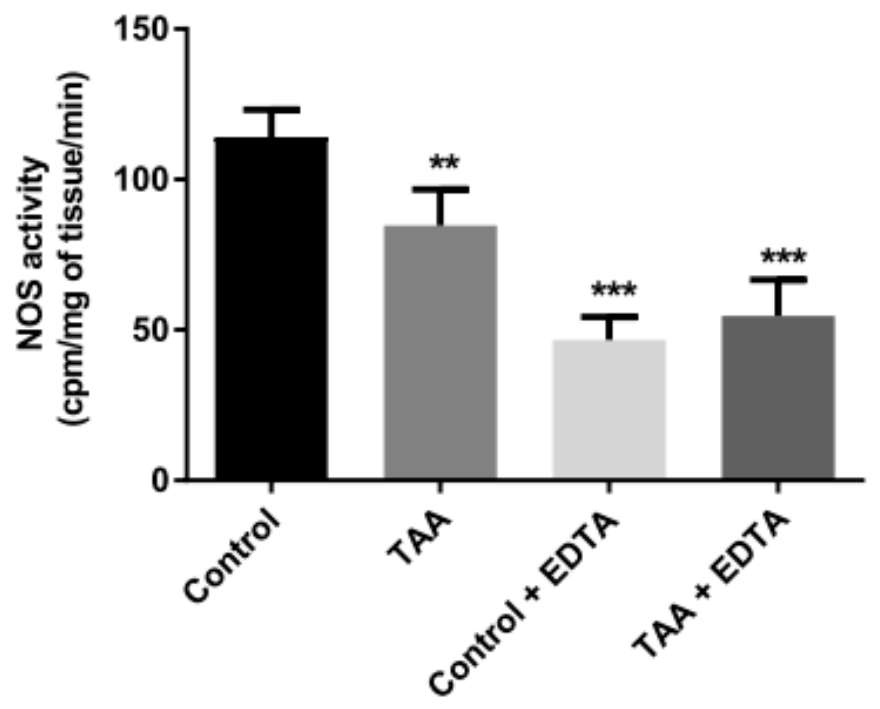

Figure 7. TAA reduces total NOS activity of rat brain prefrontal cortex Calcium ions chelation by EDTA additionally lowered NOS activity. Results are mean \pm SD $(n=5)$. Significant difference vs. control ${ }^{* *} p<0.01 ;{ }^{* * *} p<0.001$.
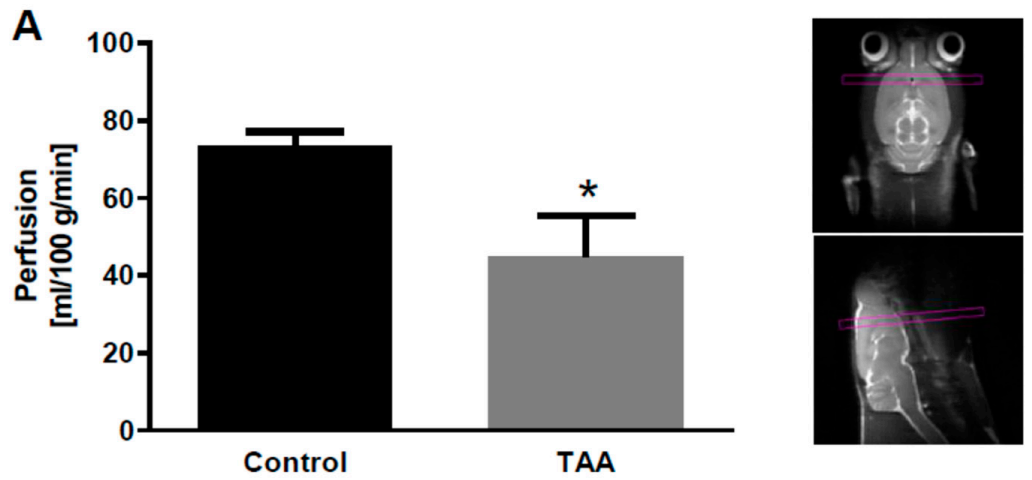

B
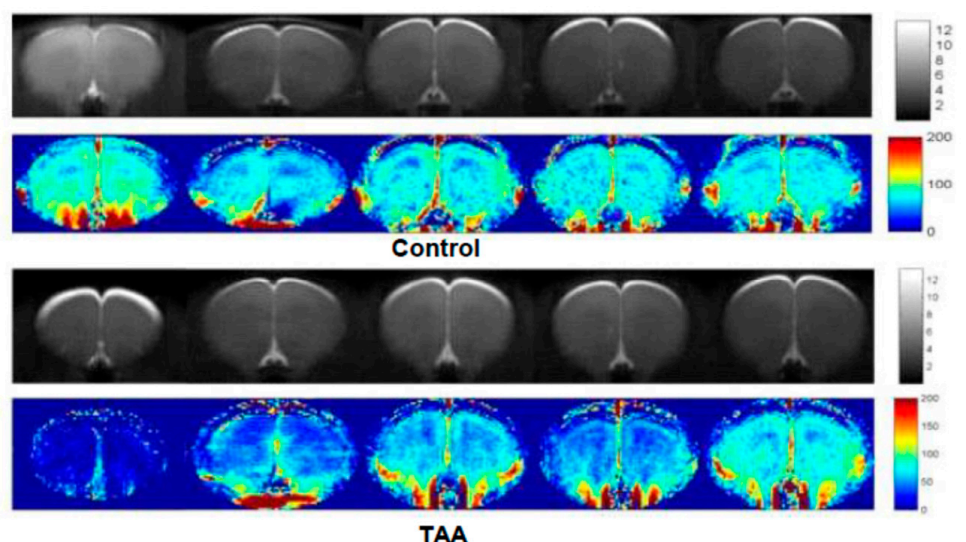

Figure 8. Magnetic resonance imaging (MRI; 3D ASL) analysis showed lowered cerebral blood flow (CBF) in the prefrontal cortex of TAA-treated rat. Pictures on the upper panel show a scanning plane (A). Below transverse plane MRI images of individual animal brains (in gray scale) and CBF (in color) (B). The red color labeling represents an increased CBF level, while blue indicates decreased CBF level. Significant difference vs. control ${ }^{*} p<0.05(\mathrm{n}=5)$. 


\section{Discussion}

The key observation of the present study is that ALF significantly impairs brain eNOS function as a consequence of both eNOS protein loss and its uncoupling, as reflected by a drop in the ratio of the active dimer to the inactive monomer. The potential of eNOS dysfunction in L-arginine-evoked ROS formation was collectively deduced from the attenuation of ROS generation by a pan inhibitor of NOS, and from the observation that L-arginine-evoked enhancement of ROS generation was abolished by $\mathrm{Ca} 2+$ ions chelation, a maneuver abrogating eNOS activity. Of note, such conditions may evoke nNOS uncoupling as well. Recently, this phenomenon was reported in brain arteries of obese rats [28], and was suggested as a contributory factor in endothelial dysfunction during atherosclerosis in apolipoprotein E knockout (apoE-/-) mice [29]. It is worthy of note that both the regulation and functions of the constitutive NOS isoforms are largely determined by their subcellular localization, which is cell type-specific and mediated by various isoforms of caveolin. This interaction is crucial for the regulation of eNOS activity in vascular endothelial cells, where the enzyme is located at the luminal plasma membrane and changes its activity in order to modulate NO synthesis [30].

Few previous studies have specifically dealt with the fate of brain eNOS in liver failure; those that exist were confined to examinations of the consequences of chronic liver failure, and unanimously reported an increase of eNOS protein expression in the brain $[14,31]$. In the ALF model in which eNOS was likewise found to be increased, ALF was induced by a hepatic devascularization, a maneuver which induces liver dysfunction by a mechanism bypassing toxic damage [23]. The opposite responses to acute and chronic liver failure are best illustrated by differences in NO signaling-related cGMP status. Acute HE is accompanied by a NO-dependent, nNOS-mediated increase of cGMP [32,33], a status reflecting acute overexposure of the brain to ammonia [34], whereas in chronic HE, the cGMP level was depressed $[35,36]$. Selective regional effects of HE on the cGMP-synthesizing soluble guanylate cyclase, an enzyme synthesizing cGMP, may have contributed to the discrepancies in these findings [37].

The mechanisms responsible for changes in eNOS expression in the present ALF model remain to be determined. Regulation of eNOS is a complex phenomenon [38]. Apart from shear stress, classic eNOS inductors include VEGF [39], TGF $\beta$ [40], and $\mathrm{H}_{2} \mathrm{O}_{2}$ [41]. By contrast, pro-inflammatory factor TNF $\alpha$ [42] and LPS [43], and hypoxia [44,45], can reduce eNOS mRNA levels. Recently, the regulatory role of IncRNAs (STEEL and LEENE) and microRNAs (miR-92a; miR221/222) in eNOS level control was investigated [46-48]. Alternatively, posttranscriptional regulation may involve mRNA stability, methylation, or acetylation of histones H3, H4 [49]. Further, posttranslational control of eNOS involves mainly phosphorylation and protein-protein interactions, thereby fine-tuning eNOS activation positively or negatively [50,51]. All in all, further studies aimed at identifying the mechanisms by which eNOS responds to ALF will have to account for multitude metabolic steps at the levels of transcription, posttranslational modifications and protein-protein interactions.

The uncoupling of eNOS that directly generates $\mathrm{O}_{2}{ }^{-}$, and further, the formation of hydrogen peroxide and peroxynitrite, depend upon the availability of the NOS substrate, L-arginine, and NOS cofactors, in particular BH4. BH4 loss in the brain of TAA-treated rats, on one hand, and the attenuating effect of exogenously added $\mathrm{BH} 4$ on ROS production on the other hand, collectively appear to support the link between eNOS uncoupling and ROS formation in the ALF-affected brain. The involvement of endogenous L-arginine as an eNOS controlling factor appears less likely. The Km of L-arginine as an eNOS substrate is approximately $2.9 \mu \mathrm{M}$, whereas intracellular L-arginine concentration in the brain is in the $\mathrm{mM}$ range [52], rendering the system less vulnerable to alterations in endogenous L-arginine content. Of note, brain L-arginine concentration was unchanged in this ALF model [53], notwithstanding its elevation in the blood [54]. One other endogenous metabolite with a potential to modulate eNOS activity is NOSs endogenous inhibitor, asymmetric dimethylarginine (ADMA), a stable L-arginine derivative [52,55]. Indeed, the concentration of ADMA is elevated in the ALF-affected brain in the TAA model $[53,56]$; 
however, increased ADMA level was also found in chronic HE [14]. The nature of this modulation deserves further study.

Concerning $\mathrm{BH} 4$, a vicious circle appears to operate, whereby free $\mathrm{O}_{2}{ }^{-}$oxidizes and inactivates $\mathrm{BH} 4$, and inversely, the uncoupled NOS isoform may contribute to $\mathrm{O}_{2}{ }^{-}$ generation in conditions where $\mathrm{BH} 4$ is deficient [57]. It has been shown that $\mathrm{NO}$ production by eNOS depends on the availability of intracellular BH4 [58]. The decrease of a brain $\mathrm{BH} 4$ evoked by ALF could be a consequence of altered BH4 synthesis pathway enzymes [59]. However, some evidence indicates that regulation of $\mathrm{BH} 4$ directly respond to changes in free radicals and nucleophilic oxidants such as hydrogen peroxide and peroxynitrite [60]. Cytochrome c, which was recently found to be elevated in a mouse ALF model [61], can also diminish $\mathrm{BH} 4$ content by direct oxidation [62].

In rat brain following focal ischemic incident, eNOS monomerization/uncoupling is coincident with decreased phosphorylation of its Ser1177 residue, even though a mechanistic coupling of the two phenomena remains to be proven [63]. In the future, it will be of interest to analyze the eNOS phosphorylation status in the ALF-affected brain.

As mentioned earlier, the uncoupling of eNOS in ALF-affected rat brain can be reconciled with, and is a likely contributor to, not only to the accumulation of ROS, but also to a number of subsequent pathogenic events. An ammonia-induced increase in ROS formation, including $\mathrm{O}_{2}{ }^{-}$[8], promotes a marked reduction in central and peripheral $\mathrm{NO}$ bioavailability by rapid reaction with $\mathrm{NO}$, leading to the formation of highly toxic and short-lived peroxynitrite anion $[64,65]$. Considerable evidence from in vivo and in vitro studies implicates, directly or indirectly, the role of tyrosine nitration in the evolution of HE symptoms, mainly brain edema [5,66-68]. Elevated brain protein nitration has been detected in the autopsy materials of HE patients with cirrhosis [69]. In turn, an increase in serum 3-nitrotyrosine, a direct product of proteins tyrosine residues nitration, is considered to be a biomarker in the diagnosis of patients with mild HE [27]. ALF in the present model likewise increases the nitration of brain protein tyrosine residues, which, at first sight, appears contradictory to the substantial decrease of total NOS activity and weakened eNOS function described here. However, these observations can be reconciled. Firstly, the accumulation of $\mathrm{O}_{2}{ }^{-}$due to eNOS uncoupling appears to be sufficient to promote the increased formation of peroxynitrite and protein nitration [70]. Of note in this context, eNOS uncoupling-related $\mathrm{O}_{2}{ }^{-}$generation and impaired $\mathrm{NO}$ signaling in cerebral microvessels were documented in GTP-cyclohydrolase I-deficient mice with BH4 loss [71]. In that study, the generation of 3-nitrotyrosine was significantly increased, whereas NO production and cGMP levels were reduced, pointing to the eNOS- independent NO molecules in diminished brain NO signaling. In turn, the subtle elevation of nNOS protein content in the brain of TAA-treated rats may be responsible for the intensified protein nitration. An elegant work carried on a mouse traumatic brain injury model using the genetic deficiency of NOS isoforms showed that nNOS, but not eNOS, is a trigger of enhanced brain protein nitration [72]. Moreover, in the brain of methamphetamine-intoxicated rats, tyrosine nitration was reported to be positively controlled by ADMA [73]. This mechanism may operate in the ALF-affected brain tissue with a concomitant increase of ADMA content $[53,56]$, pointing to the role of nNOS in this chain of events. ADMA modulates NO production, and its effect on $\mathrm{O}_{2}{ }^{-}$formation is $\mathrm{BH} 4-$ dependent. In the presence of $\mathrm{BH} 4$, ADMA selectively inhibits $\mathrm{O}_{2}{ }^{-}$generation from the enzyme. However, under conditions of nNOS depletion with $\mathrm{BH} 4, \mathrm{ADMA}$ no longer has any effect on $\mathrm{O}_{2}{ }^{-}$[74]. Importantly, in the absence of $\mathrm{BH} 4$, ADMA increases eNOS-derived $\mathrm{O}_{2}{ }^{-}$generation in a similar manner as the native substrate L-arginine, and the observed enhancement is of similar magnitude [75].

eNOS is critically involved in the maintenance of adequate cerebral blood flow (CBF) [76]. Therefore, deactivation of eNOS is a likely cause of the CBF impairment in the prefrontal cortex of TAA rats which was consistently observed in the present and in a previous study [77], as well as in studies in which different CBF recording procedures have been used [78]. Importantly in this context, several reports have implicated the participation of nNOS in CBF control (Santizo et al., 2000, Chi et al., 2003). The administration of 
a selective nNOS inhibitor, i.e., 7-nitroindazole (7-NI), depressed basal CBF in rats [79,80]. Moreover, under hyperbaric conditions, the increase in $\mathrm{CBF}$ in the cortex prior to the appearance of electrical discharges was likewise 7-NI-sensitive [81]. Therefore, further elucidation of nNOS-related CBF changes during ALF is required.

Even though CBF decrease is not a rule in ALF, a recent meta-analysis based on a representative bulk of studies confirmed that CBF decrease prevails in the majority of cases, irrespective of the causes of liver failure [82]. In this context, a decrease of cerebral perfusion resulting from the hepatic devascularization procedure precedes the increased intracranial pressure and brain edema [83]. Hence, if positively verified in other settings of ALF, the data obtained in the present study will support future considerations of brain eNOS as a contributor in the early stages of ALF.

In conclusion, we showed that the ALF induced in the TAA model resulted in a reduction of eNOS protein expression and in a decrease of the eNOS dimer/monomer ratio in the brain, but also in a partial loss of nNOS isoform. The study thus highlights the altered status of constitutive NOS isoforms as a potential contributor to brain impairment in ALF. In particular, the results show that (i) impaired expression/function of eNOS and/or nNOS, but not of iNOS, may be accounted for a decrease of NOS activity; (ii) eNOS-related aspects of brain redox status are related to the concurrent depletion of the eNOS cofactor, $\mathrm{BH} 4$; and (iii) impairment of eNOS is a likely contributor to reduced cerebral perfusion. Clearly, a detailed mechanistic analysis of the individual roles of eNOS and nNOS and their interplay in the above phenomena is merited in the future studies.

\section{Materials and Methods}

\subsection{Study Design, Acute Liver Failure Model and Biochemical Analysis}

The studies were conducted on male Sprague-Dawley rats, outbred animal colony (Tac:Cmd:SD), supplied by the Animal House of Mossakowski Medical Research Centre, Warsaw, Poland, with initial body weights from 220 to $250 \mathrm{~g}$, and kept under standard laboratory conditions at room temperature $\left(22{ }^{\circ} \mathrm{C}\right)$ under an artificial light/dark cycle $(12 / 12 \mathrm{~h})$ with free access to standard laboratory food and tap water. All procedures were performed under the National Institutes of Health Guidelines for the Care and Use of Laboratory Animals and received approval 57/2015 (14 May 2015) from the 4th Local Ethics Committee for Animal Experimentation, Warsaw, Poland, as compliant with Polish Law (of 21 January 2005). All efforts were made to reduce the number of animals and to minimize their suffering. No special medication was given to reduce pain during experiments. The study complies with the ARRIVE guidelines for reporting animal research. No randomization was performed to allocate subjects in the study. This study was not preregistered.

Acute liver failure (ALF) was induced by three intraperitoneal (ip) injections of thioacetamide (TAA, Sigma-Aldrich, Saint Louis, MO, USA), (300 mg $/ \mathrm{kg}$ body weight) at $24 \mathrm{~h}$ intervals [16]. Control rats were administered ip with the saline solution according to the analogical scheme. Animals were sacrificed $24 \mathrm{~h}$ after the last injection, with the onset of acute HE symptoms. Experiments were carried out on isolated livers and brain prefrontal cortices, using a key region for HE-dependent brain edema. Tissue samples were rapidly homogenized in a buffer appropriate to each protocol or frozen at $-80^{\circ} \mathrm{C}$. The biochemical parameters of the blood plasma were evaluated: ammonia level as the main HE factor, activities of aspartate aminotransferase, alanine aminotransferase, and $\gamma$-glutamyl transpeptidase. Markers of liver damage were analyzed by a specialized veterinary laboratory. Additionally, liver sections derived from right lobes were fixed in PBS-buffered $4 \%$ paraformaldehyde solution and standard hematoxylin and eosin staining (block preparation in paraffin, section cutting 5-6 $\mu \mathrm{m}$ thick) were made to confirm liver damage. 


\subsection{Protein Isolation, Western Blot, and eNOS Dimerization Analysis}

The prefrontal cortex was homogenized in RIPA buffer containing Protease Inhibitor Cocktail (concentration 1:200, Sigma-Aldrich, Saint Louis, MO, USA), phosphatase inhibitor cocktail (concentration 1:100, Sigma-Aldrich, Saint Louis, MO, USA) and $50 \mu \mathrm{M}$ sodium fluoride $0.5 \mathrm{M}$ (Sigma-Aldrich, Saint Louis, MO, USA) and then centrifuged for $20 \mathrm{~min}$ at $15,000 \times g$ and $4{ }^{\circ} \mathrm{C}$. The supernatants were transferred to a new Eppendorf tube. Equal amounts of protein $(30 \mu \mathrm{g})$ were separated on $10 \%$ SDS-polyacrylamide gels and transferred onto a nitrocellulose membrane. Membranes were blocked with $5 \%$ nonfat dry milk in TBS-T buffer. The membranes were then incubated overnight with anti-nNOS (1:100, Santa Cruz Biotechnologies, Dallas TX, USA) anti-iNOS (1:250 Santa Cruz Biotechnologies, Dallas, TX, USA) anti-eNOS (1:250 Santa Cruz Biotechnologies, Dallas, TX, USA) and anti-Nitro-Tyrosine antibody (1:1000 Cell Signaling, Danvers, MA, USA) followed by $1 \mathrm{~h}$ incubation with HRP-conjugated-secondary IgG antibodies (1:5000, Sigma-Aldrich, Saint Louis, MO, USA) for detection by Clarity Western ECL Substrate (Bio-Rad Laboratories, Hercules, CA, USA). The first antibody was stripped off with $0.1 \mathrm{M}$ glycine, $\mathrm{pH} 2.9$, and second incubation was performed with an antibody against glyceraldehyde 3-phosphate dehydrogenase (GAPDH) $1 \mathrm{~h}$ incubation at $20-22{ }^{\circ} \mathrm{C}$ (1:7500, HRP-60004, ProteinTech, Manchester, UK). To determine eNOS dimmers content nonboiled lysates, low-temperature SDS-PAGE and nonreducing loading buffer (Thermo Fisher Scientific, Walhalm, MA, USA) were used. The chemiluminescent signal acquisition and densitometry analysis were conducted using the G-Box system (SynGene, Cambridge, UK) and GeneTools software (SynGene, Cambridge, UK). Total protein concentration was determined by the Lowry method using Modified Lowry Protein Assay Reagent (Thermo Fisher Scientific, Walhalm, MA, USA).

\subsection{The Isolation of a Capillary Fraction}

Gray matter prepared from freshly isolated brains was homogenized in Ringer's solution and centrifuged at $1500 \times \mathrm{g}$ for $10 \mathrm{~min}$ at $4{ }^{\circ} \mathrm{C}$. The pellet was resuspended in the same buffer, and centrifugation was repeated three times under the same conditions. The final pellet was homogenized in $10 \mathrm{~mL}$ of $0.25 \mathrm{M}$ sucrose and centrifuged in a discontinuous sucrose gradient $\left(0.25: 1: 1.5 \mathrm{M}\right.$ sucrose) $\left(30,000 \times g, 30 \mathrm{~min}, 4^{\circ} \mathrm{C}\right)$. The fraction containing microvessels obtained at the bottom of the tube was collected and transferred to a $0.2 \mathrm{~mL}$ plastic tube.

\subsection{Confocal Microscopy Visualization of eNOS}

Isolated microvessels were fixed using $4 \%$ PFA for $30 \mathrm{~min}$, and then washed three times in PBS and permeabilized/blocked for $2 \mathrm{~h}$ in $5 \%$ normal goat serum with $0.1 \%$ Triton X-100 at room temperature. Next, samples were washed with PBS and stained overnight using eNOS primary antibody (1:500 Cell Signaling, Danvers, MO, USA). After standard PBS washing, samples were stained with secondary antibody conjugated with AlexaFluor 488 (Invitrogen Corp., Carlsbad, CA, USA). Cell nuclei were contrastained with DAPI (Dako, Agilent Technologies, Santa Clara, CA, USA) for $15 \mathrm{~min}$. Microvessel fraction was smeared on a microscopic slide and visualized using an Axio Observer Z.1 microscope confocal LSM 780 system (Carl Zeiss GmBH, Jena, Germany).

\subsection{NOS Activity Measurement}

NOS activity was determined using an NOS activity assay Kit (Cayman Chemical, Ann Arbor, MI, USA, \#781001). Isolated prefrontal cortex tissue of rat brains was homogenized $(1 / 5 ; w / v)$ in Assay Buffer, centrifuged $\left(10,000 \times g, 15 \mathrm{~min}, 4^{\circ} \mathrm{C}\right)$. The supernatant was used for NOS dependent conversion of $14 \mathrm{C}$ L-arginine to $14 \mathrm{C}$ L-citrulline, according to manufacturer's protocol. To distinguish the activity of the iNOS (calcium-independent) and constitutive NOS (nNOS and eNOS), the calcium was chelated by EDTA. The radioactivity was measured in a Wallac 1409 Liquid Scintillation Counter (Perkin-Elmer, Waltharm, 
MA, USA). The NOS activity was expressed as CPM (counts per minute) of radiolabeled L-citrulline per gram of tissue per min.

\subsection{Measurement of Nitrite and Nitrate}

The total nitrite and nitrate $\left(\mathrm{NOx}^{-}\right)$in brain prefrontal cortex and plasma was measured directly after tissue isolation using the Calbiochem Nitric Oxide Assay Kit (Merk, Darmstadt, Germany \# 482655), which is a simple two-step process. The first step involves the conversion of nitrate to nitrite by the enzymatic action of nitrate reductase. The second step involves the addition of 2,3-diaminonaphthalene to convert nitrite to a fluorescent compound, i.e., 1 (H)-naphthotriazole. The fluorescence intensity was measured using an excitation wavelength of $375 \mathrm{~nm}$ and an emission wavelength of $450 \mathrm{~nm}$ using Fluorescence Microplate Reader FLUOstar OMEGA (BMG Labtech, Ortenberg, Germany).

\subsection{BH4 Measurement}

The concentration of BH4 in rat blood plasma and prefrontal brain cortex was measured using Rat BH4 Elisa Kit (MyBioSource, San Diego, CA, USA, \#MBS2533582), according to manufacturer's protocol for a 96-well plate assay. Brain prefrontal cortex was homogenized in ice-cold PBS $(1 / 5 ; w / v)$ and centrifuged at $10,000 \times g$ for $5 \mathrm{~min}$, before the supernatant was collected; $50 \mu \mathrm{L}$ of freshly prepared tissue homogenate or $25 \mu \mathrm{L}$ of EDTA plasma were used per plate well. The concentration of $\mathrm{BH} 4$ in the samples was then determined spectrophotometrically at a wavelength of $450 \mathrm{~nm}$ by comparing the OD of the samples to the standard curve (range 32.5-2000 pg. BH4/mL).

\subsection{Reactive Oxygen Species Measurement}

The total content of the ROS was determined fluorometrically using 5- (and-6)-carboxy$2^{\prime}, 7^{\prime}$-dichlorodihydrofluorescein diacetate (carboxy-H2DCFDA) fluorescent probe (Invitrogen). Isolated prefrontal cortex tissue was homogenized $(1 / 5 ; w / v)$ in Locke buffer $(154 \mathrm{mM} \mathrm{NaCl}, 5.6 \mathrm{mM} \mathrm{KCl}, 1.0 \mathrm{mM} \mathrm{MgCl} 2,2.3 \mathrm{mM} \mathrm{CaCl} 2,8.6 \mathrm{mM}$ HEPES, $5.6 \mathrm{mM}$ glucose, $0.1 \mathrm{mM}$ glycine, $\mathrm{pH}$ 7.4) and diluted 10 times. Homogenate samples were incubated with NOS substrate L-arginine $(100 \mu \mathrm{M})$ and/or L-NAME $(100 \mu \mathrm{M})$, EDTA $(1 \mathrm{mM})$, BH4 $(100 \mathrm{nM})$ for $10 \mathrm{~min}$, at $22-25^{\circ} \mathrm{C}$. The dose of L-arginine was chosen based on the literature and our previous study [77]. Subsequently, $10 \mu \mathrm{M}$ carboxy-H2 DCFDA was added to each reaction mixture. Exactly $200 \mu \mathrm{L}$ of the supernatant was used in the fluorescence intensity measurement at $485 \mathrm{~nm}$ excitation and $515 \mathrm{~nm}$ emission wavelengths (FLUOstar OMEGA, BMG Labtech, Ortenberg, Germany). The intensity values were directly proportional to the intracellular ROS content.

\subsection{Cerebral Blood Flow Measurement}

Arterial spin labeling MRI study was conducted $24 \mathrm{~h}$ after the last injection of TAA or saline at the Department of Magnetic Resonance Imaging, Institute of Nuclear Physics, Polish Academy of Sciences, Kraków. Experiments were performed exactly as described Czarnecka et al., 2018) using a 9.4 T (BioSpec 94/20 USR, Bruker, Germany) scanner. In brief, high-resolution anatomic images from the prefrontal cortex were acquired with spin-echo RARE (Rapid Acquisition with Relaxation Enhancement) sequence. For T1 relaxation time and tissue perfusion measurement, the FAIR-RARE (Flow-sensitive Alternating Inversion Recovery) sequence was used. Quantitative calculations were performed using an ad hoc Matlab (The MathWorks Inc., Natick, MA, USA) script.

\subsection{Statistical Analysis}

$t$-tests for unpaired samples were used to compare values between control and TAA groups with a Welch's test for unequal variances. Statistical analysis of CBF was carried out by the two-sample Mann-Whitney U test for independent observations. Statistical differences among the means of more groups were evaluated by one-way ANOVA with a post hoc Dunnet's test. All analyses were performed using 5.0 Graph Pad software 
(Graphpad Software Inc, La Jolla, CA, USA). Values were expressed as mean \pm S.D. Significance was defined as $p<0.05$ for all tests.

Author Contributions: Conceptualization, K.M. and M.Z.; methodology, K.M. and A.M.C.; investigation, K.M. and A.M.C.; data curation; K.M. and A.M.C.; visualization, K.M. and M.Z.; writingoriginal draft preparation, K.M. and M.Z.; writing — review and editing, K.M., A.M.C., J.A. and M.Z.; project administration, M.Z.; funding acquisition, M.Z. All authors have read and agreed to the published version of the manuscript.

Funding: This research was funded by National Science Centre of the Republic of Poland (NCN), grant number: 2013/09/B/NZ4/00536 and No 2015/19/B/NZ4/01902.

Institutional Review Board Statement: The study was conducted according to the guidelines of the Declaration of Helsinki, and approved by the Bioethics Commission (approval protocol code 57/2015, date of approval 14 May 2015.

Informed Consent Statement: Not applicable.

Data Availability Statement: Data available on request.

Acknowledgments: We gratefully acknowledge the contribution of Krzysztof Jasiński from the Institute of Nuclear Physics, Polish Academy of Sciences, Kraków, who contributed in MRI measurements and data analysis.

Conflicts of Interest: The authors declare no conflict of interest.

$\begin{array}{ll}\text { Abbreviations } \\ \text { ALF } & \text { Acute liver failure } \\ \text { BBB } & \text { Blood-brain barrier } \\ \text { BH4 } & \text { Tetrahydrobiopterin } \\ \text { CBF } & \text { Cerebral blood flow } \\ \text { eNOS } & \text { Endothelial nitric oxide synthase } \\ \text { HE } & \text { Hepatic encephalopathy } \\ \text { NO } & \text { Nitric oxide } \\ \text { nNOS } & \text { Neuronal nitric oxide synthase } \\ \text { ONS } & \text { Oxidative nitrosative stress } \\ \text { ROS } & \text { Reactive oxygen species } \\ \text { TAA } & \text { Thioacetamide } \\ \text { TCA } & \text { Tricarboxylic acid }\end{array}$

\section{References}

1. Prakash, R.; Mullen, K.D. Mechanisms, diagnosis and management of hepatic encephalopathy. Nat. Rev. Gastroenterol. Hepatol. 2010, 7, 515-525. [CrossRef]

2. Felipo, V. Hepatic encephalopathy: Effects of liver failure on brain function. Nat. Rev. Neurosci. 2013, 14, 851-858. [CrossRef] [PubMed]

3. Liere, V.; Sandhu, G.; De Morrow, S. Recent advances in hepatic encephalopathy. F1000Research 2017, 6, 1637. [CrossRef]

4. McPhail, M.J.; Bajaj, J.S.; Thomas, H.C.; Taylor-Robinson, S.D. Pathogenesis and diagnosis of hepatic encephalopathy. Expert Rev. Gastroenterol. Hepatol. 2010, 4, 365-378. [CrossRef]

5. Gorg, B.; Schliess, F.; Haussinger, D. Osmotic and oxidative/nitrosative stress in ammonia toxicity and hepatic encephalopathy. Arch. Biochem. Biophys. 2013, 536, 158-163. [CrossRef]

6. Gorg, B.; Karababa, A.; Schutz, E.; Paluschinski, M.; Schrimpf, A.; Shafigullina, A.; Castoldi, M.; Bidmon, H.J.; Haussinger, D. O-GlcNAcylation-dependent upregulation of $\mathrm{HO} 1$ triggers ammonia-induced oxidative stress and senescence in hepatic encephalopathy. J. Hepatol. 2019, 71, 930-941. [CrossRef]

7. Shawcross, D.L.; Sharifi, Y.; Canavan, J.B.; Yeoman, A.D.; Abeles, R.D.; Taylor, N.J.; Auzinger, G.; Bernal, W.; Wendon, J.A. Infection and systemic inflammation, not ammonia, are associated with Grade $3 / 4$ hepatic encephalopathy, but not mortality in cirrhosis. J. Hepatol. 2011, 54, 640-649. [CrossRef]

8. Reinehr, R.; Gorg, B.; Becker, S.; Qvartskhava, N.; Bidmon, H.J.; Selbach, O.; Haas, H.L.; Schliess, F.; Haussinger, D. Hypoosmotic swelling and ammonia increase oxidative stress by NADPH oxidase in cultured astrocytes and vital brain slices. Glia 2007, 55, 758-771. [CrossRef] 
9. Youn, J.Y.; Gao, L.; Cai, H. The p47phox- and NADPH oxidase organiser 1 (NOXO1)-dependent activation of NADPH oxidase 1 (NOX1) mediates endothelial nitric oxide synthase (eNOS) uncoupling and endothelial dysfunction in a streptozotocin-induced murine model of diabetes. Diabetologia 2012, 55, 2069-2079. [CrossRef]

10. Li, Q.; Youn, J.-Y.; Cai, H. Mechanisms and consequences of endothelial nitric oxide synthase dysfunction in hypertension. J. Hypertens. 2015, 33, 1128-1136. [CrossRef]

11. Palenzuela, L.; Oria, M.; Romero-Giménez, J.; Garcia-Lezana, T.; Chavarria, L.; Cordoba, J. Gene expression profiling of brain cortex microvessels may support brain vasodilation in acute liver failure rat models. Metab. Brain Dis. 2016, 31, 1405-1417. [CrossRef]

12. Siragusa, M.; Fleming, I. The eNOS signalosome and its link to endothelial dysfunction. Pflügers Arch. Eur. J. Physiol. 2016, 468, 1125-1137. [CrossRef] [PubMed]

13. Hong, W.K.; Shim, K.Y.; Baik, S.K.; Kim, M.Y.; Cho, M.Y.; Jang, Y.O.; Park, Y.S.; Han, J.; Kim, G.; Cho, Y.Z.; et al. Relationship between Tetrahydrobiopterin and Portal Hypertension in Patients with Chronic Liver Disease. J. Korean Med. Sci. 2014, 29, 392-399. [CrossRef]

14. Balasubramaniyan, V.; Wright, G.; Sharma, V.; Davies, N.A.; Sharifi, Y.; Habtesion, A.; Mookerjee, R.P.; Jalan, R. Ammonia reduction with ornithine phenylacetate restores brain eNOS activity via the DDAH-ADMA pathway in bile duct-ligated cir-rhotic rats. Am. J. Physiol. Gastrointest. Liver Physiol. 2012, 302, G145-G152. [CrossRef]

15. Matei, V.; Rodriguez-Vilarrupla, A.; Deulofeu, R.; Colomer, D.; Fernandez, M.; Bosch, J.; Garcia-Pagan, J.C. The eNOS cofactor tetrahydrobiopterin improves endothelial dysfunction in livers of rats with CCl4 cirrhosis. Hepatology 2006, 44, 44-52. [CrossRef]

16. Hilgier, W.; Olson, J.E. Brain Ion and Amino Acid Contents During Edema Development in Hepatic Encephalopathy. J. Neurochem. 1994, 62, 197-204. [CrossRef] [PubMed]

17. Schemitt, E.G.; Hartmann, R.M.; Colares, J.R.; Licks, F.; Salvi, J.O.; Marroni, C.A.; Marroni, N.P. Protective action of glutamine in rats with severe acute liver failure. World J. Hepatol. 2019, 11, 273-286. [CrossRef]

18. Mohi-Ud-Din, R.; Mir, R.H.; Sawhney, G.; Dar, M.A.; Bhat, Z.A. Possible Pathways of Hepatotoxicity Caused by Chemical Agents. Curr. Drug Metab. 2019, 20, 867-879. [CrossRef]

19. Sekine, A.; Fukuwatari, T. Acute liver failure increases kynurenic acid production in rat brain via changes in tryptophan metabolism in the periphery. Neurosci. Lett. 2019, 701, 14-19. [CrossRef] [PubMed]

20. Rahman, T.M.; Hodgson, H.J.F. Animal models of acute hepatic failure. Int. J. Exp. Pathol. 2000, 81, 145-157. [CrossRef]

21. Butterworth, R.F.; Norenberg, M.D.; Felipo, V.; Ferenci, P.; Albrecht, J.; Blei, A.T. Experimental models of hepatic encephalopathy: ISHEN guidelines. Liver Int. 2009, 29, 783-788. [CrossRef]

22. Huang, H.-C.; Wang, S.-S.; Chan, C.-Y.; Chen, Y.-C.; Lee, F.-Y.; Chang, F.-Y.; Chu, C.-J.; Lin, H.-C.; Lu, R.-H.; Lee, S.-D. Role of Hepatic Nitric Oxide Synthases in Rats with Thioacetamide-induced Acute Liver Failure and Encephalopathy. J. Chin. Med. Assoc. 2007, 70, 16-23. [CrossRef]

23. Jiang, W.; Desjardins, P.; Butterworth, R.F. Direct evidence for central proinflammatory mechanisms in rats with experimental acute liver failure: Protective effect of hypothermia. J. Cereb. Blood Flow Metab. Off. J. Int. Soc. Cereb. Blood Flow Metab. 2009, 29, 944-952. [CrossRef]

24. Pacher, P.; Beckman, J.S.; Liaudet, L. Nitric Oxide and Peroxynitrite in Health and Disease. Physiol. Rev. 2007, 87, 315-424. [CrossRef]

25. Shishehbor, M.H.; Aviles, R.J.; Brennan, M.-L.; Fu, X.; Goormastic, M.; Pearce, G.L.; Gokce, N.; Keaney, J.J.F.; Penn, M.S.; Sprecher, D.L.; et al. Association of Nitrotyrosine Levels with Cardiovascular Disease and Modulation by Statin Therapy. JAMA 2003, 289, 1675-1680. [CrossRef]

26. Winyard, P.G.; Ryan, B.; Eggleton, P.; Nissim, A.; Taylor, E.; Faro, M.L.L.; Burkholz, T.; Szabó-Taylor, K.E.; Fox, B.; Viner, N.; et al. Measurement and meaning of markers of reactive species of oxygen, nitrogen and sulfur in healthy human subjects and patients with inflammatory joint disease. Biochem. Soc. Trans. 2011, 39, 1226-1232. [CrossRef]

27. Montoliu, C.; Cauli, O.; Urios, A.; El Mlili, N.; Serra, M.A.; Giner-Duran, R.; Gonzalez-Lopez, O.; del Olmo, J.A.; Wassel, A.; Rodrigo, J.M.; et al. 3-nitro-tyrosine as a peripheral biomarker of minimal hepatic encephalopathy in patients with liver cirrhosis. Am. J. Gastroenterol. 2011, 106, 1629-1637. [CrossRef]

28. Katakam, P.V.; Snipes, J.A.; Steed, M.M.; Busija, D.W. Insulin-induced generation of reactive oxygen species and uncou-pling of nitric oxide synthase underlie the cerebrovascular insulin resistance in obese rats. J. Cereb. Blood Flow Metab. Off. J. Int. Soc. Cereb. Blood Flow Metab. 2012, 32, 792-804. [CrossRef]

29. Ponnuswamy, P.; Ostermeier, E.; Schröttle, A.; Chen, J.; Huang, P.L.; Ertl, G.; Nieswandt, B.; Kuhlencordt, P.J. Oxidative Stress and Compartment of Gene Expression Determine Proatherosclerotic Effects of Inducible Nitric Oxide Synthase. Am. J. Pathol. 2009, 174, 2400-2410. [CrossRef]

30. Chidlow, J.H.; Sessa, W.C. Caveolae, caveolins, and cavins: Complex control of cellular signalling and inflammation. Cardiovasc. Res. 2010, 86, 219-225. [CrossRef]

31. Hernández, R.; Martínez-Lara, E.; del Moral, M.L.; Blanco, S.; Cañuelo, A.; Siles, E.; Esteban, F.J.; Pedrosa, J.A.; Peinado, M.A. Upregulation of endothelial nitric oxide synthase maintains nitric oxide production in the cerebellum of thioacetamide cirrhotic rats. Neuroscience 2004, 126, 879-887. [CrossRef]

32. Hermenegildo, C.; Monfort, P.; Felipo, V. Activation of N-methyl-D-aspartate receptors in rat brainin vivo following acute ammonia intoxication: Characterization byin vivo brain microdialysis. Hepatology 2000, 31, 709-715. [CrossRef] 
33. Schneider, F.; Lutun, P.; Boudjema, K.; Wolf, P.; Tempe, J.D. In vivo evidence of enhanced guanylyl cyclase activation dur-ing the hyperdynamic circulation of acute liver failure. Hepatology 1994, 19, 38-44. [CrossRef] [PubMed]

34. Hilgier, W.; Anderzhanova, E.; Oja, S.S.; Saransaari, P.; Albrecht, J. Taurine reduces ammonia- and N-methyl-d-aspartate-induced accumulation of cyclic GMP and hydroxyl radicals in microdialysates of the rat striatum. Eur. J. Pharmacol. 2003, 468, 21-25. [CrossRef]

35. Llansola, M.; Rodrigo, R.; Monfort, P.; Montoliu, C.; Kosenko, E.; Cauli, O.; Piedrafita, B.; El Mlili, N.; Felipo, V. NMDA receptors in hyperammonemia and hepatic encephalopathy. Metab. Brain Dis. 2007, 22, 321-335. [CrossRef] [PubMed]

36. Rodrigo, R.; Felipo, V. Brain regional alterations in the modulation of the glutamate-nitric oxide-cGMP pathway in liver cirrhosis. Role of hyperammonemia and cell types involved. Neurochem. Int. 2006, 48, 472-477. [CrossRef]

37. Corbalán, R.; Chatauret, N.; Behrends, S.; Butterworth, R.F.; Felipo, V. Region selective alterations of soluble guanylate cyclase content and modulation in brain of cirrhotic patients. Hepatology 2002, 36, 1155-1162. [CrossRef] [PubMed]

38. Nishida, K.; Harrison, D.G.; Navas, J.P.; Fisher, A.A.; Dockery, S.P.; Uematsu, M.; Nerem, R.M.; Alexander, R.W.; Murphy, T.J. Molecular cloning and characterization of the constitutive bovine aortic endothelial cell nitric oxide synthase. J. Clin. Investig. 1992, 90, 2092-2096. [CrossRef]

39. Bouloumie, A.; Schini-Kerth, V.B.; Busse, R. Vascular endothelial growth factor up-regulates nitric oxide synthase expression in endothelial cells. Cardiovasc. Res. 1999, 41, 773-780. [CrossRef]

40. Saura, M.; Zaragoza, C.; Cao, W.; Bao, C.; Rodriguez-Puyol, M.; Rodriguez-Puyol, D.; Lowenstein, C.J. Smad2 mediates transforming growth factor-beta induction of endothelial nitric oxide synthase expression. Circ. Res. 2002, 91, 806-813. [CrossRef]

41. Searles, C.D. Transcriptional and posttranscriptional regulation of endothelial nitric oxide synthase expression. Am. J. Physiol.-Cell Physiol. 2006, 291, C803-C816. [CrossRef]

42. Neumann, P.; Gertzberg, N.; Johnson, A. TNF- $\alpha$ induces a decrease in eNOS promoter activity. Am. J. Physiol. Cell. Mol. Physiol. 2004, 286, L452-L459. [CrossRef]

43. Lu, J.L.; Schmiege, L.M., III; Kuo, L.; Liao, J.C. Downregulation of endothelial constitutive nitric oxide synthase expres-sion by lipopolysaccharide. Biochem. Biophys. Res. Commun. 1996, 225, 1-5. [CrossRef]

44. McQuillan, L.P.; Leung, G.K.; Marsden, P.A.; Kostyk, S.K.; Kourembanas, S. Hypoxia inhibits expression of eNOS via transcriptional and posttranscriptional mechanisms. Am. J. Physiol. Circ. Physiol. 1994, 267, H1921-H1927. [CrossRef]

45. Pedersen, C.L.; Faggiano, S.; Helbo, S.; Gesser, H.; Fago, A. Roles of nitric oxide, nitrite and myoglobin on myocardial efficiency in trout (Oncorhynchus mykiss) and goldfish (Carassius auratus): Implications for hypoxia tolerance. J. Exp. Biol. 2010, 213, $2755-2762$. [CrossRef]

46. Bonauer, A.; Carmona, G.; Iwasaki, M.; Mione, M.; Koyanagi, M.; Fischer, A.; Burchfield, J.; Fox, H.; Doebele, C.; Ohtani, K.; et al. MicroRNA-92a controls angiogenesis and functional recovery of ischemic tissues in mice. Science 2009, 324, 1710-1713. [CrossRef] [PubMed]

47. Qin, B.; Shu, Y.; Long, L.; Li, H.; Men, X.; Feng, L.; Yang, H.; Lu, Z. MicroRNA-142-3p Induces Atherosclerosis-Associated Endothelial Cell Apoptosis by Directly Targeting Rictor. Cell. Physiol. Biochem. 2018, 47, 1589-1603. [CrossRef]

48. Miao, Y.; Ajami, N.E.; Huang, T.-S.; Lin, F.-M.; Lou, C.-H.; Wang, Y.-T.; Li, S.; Kang, J.; Munkacsi, H.; Maurya, M.R.; et al. Enhancer-associated long non-coding RNA LEENE regulates endothelial nitric oxide synthase and endothelial function. Nat. Commun. 2018, 9, 1-13. [CrossRef]

49. Garcia, V.; Sessa, W.C. Endothelial NOS: Perspective and recent developments. Br. J. Pharmacol. 2019, 176, 189-196. [CrossRef]

50. Bauer, P.M.; Fulton, D.; Boo, Y.C.; Sorescu, G.P.; Kemp, B.E.; Jo, H.; Sessa, W.C. Compensatory phosphorylation and protein-protein interactions revealed by loss of function and gain of function mutants of multiple serine phosphorylation sites in endothelial nitric-oxide synthase. J. Biol. Chem. 2003, 278, 14841-14849. [CrossRef]

51. Mount, P.F.; Kemp, B.E.; Power, D.A. Regulation of endothelial and myocardial NO synthesis by multi-site eNOS phos-phorylation. J. Mol. Cell. Cardiol. 2007, 4, 271-279. [CrossRef] [PubMed]

52. Karbach, S.; Wenzel, P.; Waisman, A.; Munzel, T.; Daiber, A. eNOS uncoupling in cardiovascular diseases-the role of oxida-tive stress and inflammation. Curr. Pharm. Des. 2014, 20, 3579-3594. [CrossRef] [PubMed]

53. Milewski, K.; Hilgier, W.; Albrecht, J.; Zielinska, M. The dimethylarginine (ADMA)/nitric oxide pathway in the brain and periphery of rats with thioacetamide-induced acute liver failure: Modulation by histidine. Neurochem. Int. 2015, 88, 26-31. [CrossRef] [PubMed]

54. Milewski, K.; Hilgier, W.; Fresko, I.; Polowy, R.; Podsiadlowska, A.; Zolocinska, E.; Grymanowska, A.W.; Filipkowski, R.K.; Albrecht, J.; Zielinska, M. Carnosine Reduces Oxidative Stress and Reverses Attenuation of Righting and Postural Re-flexes in Rats with Thioacetamide-Induced Liver Failure. Neurochem. Res. 2016, 41, 376-384. [CrossRef]

55. Sydow, K.; Münzel, T. ADMA and oxidative stress. Atheroscler. Suppl. 2003, 4, 41-51. [CrossRef]

56. Czarnecka, A.; Milewski, K.; Jaźwiec, R.; Zielińska, M. Intracerebral Administration of S-Adenosylhomocysteine or SAdenosylmethionine Attenuates the Increases in the Cortical Extracellular Levels of Dimethylarginines Without Affecting cGMP Level in Rats with Acute Liver Failure. Neurotox. Res. 2016, 31, 99-108. [CrossRef] [PubMed]

57. Forstermann, U.; Munzel, T. Endothelial nitric oxide synthase in vascular disease: From marvel to menace. Circulation 2006, 113, 1708-1714. [CrossRef] [PubMed] 
58. Rosenkranz-Weiss, P.; Sessa, W.C.; Milstien, S.; Kaufman, S.; Watson, C.A.; Pober, J.S. Regulation of nitric oxide synthesis by proinflammatory cytokines in human umbilical vein endothelial cells. Elevations in tetrahydrobiopterin levels enhance endothelial nitric oxide synthase specific activity. J. Clin. Investig. 1994, 93, 2236-2243. [CrossRef] [PubMed]

59. Werner, E.R.; Blau, N.; Thony, B. Tetrahydrobiopterin: Biochemistry and pathophysiology. Biochem. J. 2011, 438, 397-414. [CrossRef] [PubMed]

60. Vásquez-Vivar, J. Tetrahydrobiopterin, superoxide, and vascular dysfunction. Free Radic. Biol. Med. 2009, 47, 1108-1119. [CrossRef] [PubMed]

61. Ullah, R.; Jo, M.H.; Riaz, M.; Alam, S.I.; Saeed, K.; Ali, W.; Rehman, I.U.; Ikram, M.; Kim, M.O. Glycine, the smallest amino acid, confers neuroprotection against d-galactose-induced neurodegeneration and memory impairment by regulating c-Jun N-terminal kinase in the mouse brain. J. Neuroinflamm. 2020, 17, 303. [CrossRef]

62. Capeillere-Blandin, C.; Mathieu, D.; Mansuy, D. Reduction of ferric haemoproteins by tetrahydropterins: A kinetic study. Biochem. J. 2005, 392, 583-587. [CrossRef] [PubMed]

63. Yagita, Y.; Kitagawa, K.; Oyama, N.; Yukami, T.; Watanabe, A.; Sasaki, T.; Mochizuki, H. Functional deterioration of endo-thelial nitric oxide synthase after focal cerebral ischemia. J. Cereb. Blood Flow Metab. Off. J. Int. Soc. Cereb. Blood Flow Metab. 2013, 33, 1532-1539. [CrossRef] [PubMed]

64. Ferrer-Sueta, G.; Campolo, N.; Trujillo, M.; Bartesaghi, S.; Carballal, S.; Romero, N.; Alvarez, B.; Radi, R. Biochemistry of Peroxynitrite and Protein Tyrosine Nitration. Chem. Rev. 2018, 118, 1338-1408. [CrossRef]

65. Lang, J.; Marechal, A.; Couture, M.; Santolini, J. Reaction Intermediates and Molecular Mechanism of Peroxynitrite Activation by NO Synthases. Biophys. J. 2016, 111, 2099-2109. [CrossRef]

66. Schliess, F.; Görg, B.; Fischer, R.; Desjardins, P.; Bidmon, H.J.; Herrmann, A.; Butterworth, R.F.; Zilles, K.; Häussinger, D. Ammonia induces MK-801-sensitive nitration and phosphorylation of protein tyrosine residues in rat astrocytes. FASEB J. 2002, 16, 739-741. [CrossRef] [PubMed]

67. Zielinska, M.; Milewski, K.; Skowronska, M.; Gajos, A.; Zieminska, E.; Beresewicz, A.; Albrecht, J. Induction of inducible nitric oxide synthase expression in ammonia-exposed cultured astrocytes is coupled to increased arginine transport by up-regulated $\mathrm{y}(+)$ LAT2 transporter. J. Neurochem. 2015, 135, 1272-1281. [CrossRef] [PubMed]

68. Haussinger, D.; Gorg, B. Interaction of oxidative stress, astrocyte swelling and cerebral ammonia toxicity. Curr. Opin. Clin. Nutr. Metab. Care 2010, 13, 87-92. [CrossRef] [PubMed]

69. Görg, B.; Qvartskhava, N.; Bidmon, H.-J.; Palomero-Gallagher, N.; Kircheis, G.; Zilles, K.; Häussinger, D. Oxidative stress markers in the brain of patients with cirrhosis and hepatic encephalopathy. Hepatology 2010, 52, 256-265. [CrossRef]

70. El-Remessy, A.B.; Abou-Mohamed, G.; Caldwell, R.W.; Caldwell, R.B. High glucose-induced tyrosine nitration in endothelial cells: Role of eNOS uncoupling and aldose reductase activation. Investig. Ophthalmol. Vis. Sci. 2003, 44, 3135-3143. [CrossRef]

71. Santhanam, A.V.R.; d’Uscio, L.V.; Smith, L.A.; Katusic, Z.S. Uncoupling of eNOS causes superoxide anion production and impairs NO signaling in the cerebral microvessels of hph-1 mice. J. Neurochem. 2012, 122, 1211-1218. [CrossRef] [PubMed]

72. Bayir, H.; Kagan, V.E.; Clark, R.S.; Janesko-Feldman, K.; Rafikov, R.; Huang, Z.; Zhang, X.; Vagni, V.; Billiar, T.R.; Kochanek, P.M. Neuronal NOS-mediated nitration and inactivation of manganese superoxide dismutase in brain after experimental and human brain injury. J. Neurochem. 2007, 101, 168-181. [CrossRef] [PubMed]

73. Zhang, F.; Chen, L.; Liu, C.; Qiu, P.; Wang, A.; Li, L.; Wang, H. Up-regulation of protein tyrosine nitration in methamphet-amineinduced neurotoxicity through DDAH/ADMA/NOS pathway. Neurochem. Int. 2013, 62, 1055-1064. [CrossRef] [PubMed]

74. Cardounel, A.J.; Xia, Y.; Zweier, J.L. Endogenous methylarginines modulate superoxide as well as nitric oxide generation from neuronal nitric-oxide synthase: Differences in the effects of monomethyl- and dimethylarginines in the presence and absence of tetrahydrobiopterin. J. Biol. Chem. 2005, 280, 7540-7549. [CrossRef] [PubMed]

75. Druhan, L.J.; Forbes, S.P.; Pope, A.J.; Chen, C.A.; Zweier, J.L.; Cardounel, A.J. Regulation of eNOS-derived superoxide by endogenous methylarginines. Biochemistry 2008, 47, 7256-7263. [CrossRef]

76. Garry, P.S.; Ezra, M.; Rowland, M.J.; Westbrook, J.; Pattinson, K.T. The role of the nitric oxide pathway in brain injury and its treatment-From bench to bedside. Exp. Neurol. 2015, 263, 235-243. [CrossRef] [PubMed]

77. Czarnecka, A.; Aleksandrowicz, M.; Jasinski, K.; Jazwiec, R.; Kalita, K.; Hilgier, W.; Zielinska, M. Cerebrovascular reactivity and cerebral perfusion of rats with acute liver failure: Role of L-glutamine and asymmetric dimethylarginine in L-arginine-induced response. J. Neurochem. 2018, 147, 692-704. [CrossRef]

78. Pluta, R.; Albrecht, J. Changes in arterial and cerebral venous blood gases, cerebral blood flow and cerebral oxygen con-sumption at different stages of thioacetamide-induced hepatogenic encephalopathy in rat. Resuscitation 1986, 14, 135-139. [PubMed]

79. Montécot, C.; Borredon, J.; Seylaz, J.; Pinard, E. Nitric Oxide of Neuronal Origin is Involved in Cerebral Blood Flow Increase during Seizures Induced by Kainate. Br. J. Pharmacol. 1997, 17, 94-99. [CrossRef]

80. Gotoh, J.; Kuang, T.-Y.; Nakao, Y.; Cohen, D.M.; Melzer, P.; Itoh, Y.; Pak, H.; Pettigrew, K.; Sokoloff, L. Regional differences in mechanisms of cerebral circulatory response to neuronal activation. Am. J. Physiol. Heart Circ. Physiol. 2001, 280, H821-H829. [CrossRef] [PubMed]

81. Hagioka, S.; Takeda, Y.; Zhang, S.; Sato, T.; Morita, K. Effects of 7-nitroindazole and N-nitro-l-arginine methyl ester on changes in cerebral blood flow and nitric oxide production preceding development of hyperbaric oxygen-induced seizures in rats. Neurosci. Lett. 2005, 382, 206-210. [CrossRef] [PubMed] 
82. Bjerring, P.N.; Gluud, L.L.; Larsen, F.S. Cerebral Blood Flow and Metabolism in Hepatic Encephalopathy-A Meta-Analysis. J. Clin. Exp. Hepatol. 2018, 8, 286-293. [CrossRef] [PubMed]

83. Shah, V.; Webster, S.; Gottstein, J.; Blei, A.T. Reduction of cerebral perfusion precedes rise of intracranial pressure in rats with ischemic fulminant liver failure. Hepatology 1993, 17, 1117-1122. [PubMed] 